\title{
Karakteristik Silase Semak Bunga Putih (Chromolaena odorata) dengan Penambahan Jenis Karbohidrat Terlarut yang Berbeda
}

\author{
Characteristics of Silage Chromolaena odorata With the Addition of Different Types \\ Dissolved Carbohydrates
}

\author{
G. F. Bira*, P. K. Tahuk, K. W. Kia, S. K. Hartun dan F. Nitsae \\ Program Studi Peternakan, Fakultas Pertanian, Universitas Timor \\ J1. Km 09 Kelurahan Sasi, Kecamatan Kota Kefamenanu, Kabupaten TTU-NTT, 85613 \\ Corresponding e-mail: gersonbira@yahoo.co.id
}

\begin{abstract}
The aimed of this study was to determine the characteristics of the silage of Chromolaena odorata which were added with different types of dissolved carbohydrates. The study used a completely randomized design (CRD) with 4 treatments and 4 replications. The treatments consisted of R0: Chromolaena odorata $(70 \%)+$ Leucaena leucocephala (30\%) (control), R1: Chromolaena odorata (70\%) + Leucaena leucocephala (20\%) + Rice Bran (10\%), R2: Chromolaena odorata (70\%) + Leucaena leucocephala (20\%) + Cassava Flour (10\%), R3: Leucaena leucocephala $(70 \%)+$ Leucaena leucocephala $(20 \%)+$ Corn flour (10\%), Percentage of rice bran, corn flour and cassava flour calculated based on the chopped weight of Chromolaena odorata and Leucaena leucocephala leaves in wilted conditions. The variables studied were physical (organoleptic) and chemical (proximate) characteristics of Chromolaena odorata silage. The results showed that the addition of dissolved carbohydrates significantly affected the physical and chemical characteristics of silage. It was concluded that the addition of cassava flour had a significantly higher effect and significantly higher in producing the best physical characteristics of Chromolaena odorata silage. While the chemical characteristics, the addition of rice bran as a dissolved carbohydrate was significantly higher than that of cassava flour and corn flour.
\end{abstract}

Key word : characteristics of silage, Chromolaena odorata, dissolved carbohydrates

\begin{abstract}
ABSTRAK
Penelitian bertujuan untuk mengetahui karakteristik silase semak bunga putih (Chromolaena odorata) yang ditambahkan jenis karbohdirat terlarut yang berbeda. Penelitian menggunakan Rancangan Acak Lengkap (RAL) dengan 4 perlakuan dan 4 ulangan. Perlakuan terdiri dari R0 : Semak bunga putih $(70 \%)+$ Lamtoro $(30 \%)$ (kontrol), R1 : Semak bunga putih (70\%) + Lamtoro (20\%) + Dedak Padi (10\%), R2 : Semak bunga putih (70\%) + Lamtoro (20\%) + Tepung Gaplek (10\%), R3 : Semak bunga putih (70\%) + Lamtoro (20\%) + Tepung Jagung (10\%), Persentase dedak padi, tepung jagung dan tepung gaplek dihitung berdasarkan berat cacahan daun SBP dan lamtoro dalam kondisi layu. Variabel yang diteliti adalah karakteristik fisik (organoleptik) dan kimia (proksimat) silase semak bunga putih. Hasil penelitian menunjukkan penambahan karbohidrat terlarut berpengaruh nyata terhadap karaktersitik fisik dan kimia silase. Disimpulkan bahwa penambahan tepung gaplek berpengaruh dan nyata lebih tinggi dalam menghasilkan karakteristik fisik silase semak bunga putih yang terbaik. sedangkan karakteristik kimia, penambahan dedak padi sebagai karbohidrat terlarut nyata lebih tinggi dibandingkan dengan tepung gaplek dan tepung jagung.
\end{abstract}

Kata kunci : karakteristik silase, Chromolaena odorata, karbohidrat terlarut

\section{PENDAHULUAN}

Pada umumnya ada beberapa faktor yang mempengaruhi produktivitas ternak diantaranya adalah pakan, manajemen dan faktor bibit. Diantara ketiga faktor tersebut pakan mempunyai persentase terbesar yang sangat menentukan keberhasilan dalam beternak. Sebagai faktor penentu maka pakan harus diperhatikan secara menyeluruh baik dalam kualitas, kuantitas dan kontinyuitasnya. Persoalan pakan pada peternakan lahan kering merupakan hal yang sering terjadi. Mengingat musim hujan yang singkat dan musim kemarau yang berkepanjangan. Pada saat hujan produksi biomasa tanaman pakan melimpah sedangkan pada musim kemarau produksinya menurun tajam (Tahuk et al., 2020). Hal ini menyebabkan produktivitas ternak cukup berfluktuatif tergantung kondisi lingkungan.

Hal yang dapat dilakukan adalah mencari sumber pakan lain yang kualitasnya sama dengan 
pakan non konvensional serta tetap tersedia disepanjang musim. Chromolaena odorata atau yang lebih dikenal dengan semak bunga putih (SBP) telah menjadi ancaman bagi peternakan di Propinsi Nusa Tenggara Timur (NTT) dewasa ini. Semak bunga putih telah menginvasi dan mendominasi hampir di semua lahan dan padang penggembalaan alam yang ada di NTT, penyebarannya sangat cepat serta daya adaptasi yang sangat tinggi menjadikan SBP sangat ditakuti. SBP yang selama ini telah menjadi musuh besar bagi lahan pertanian dan perkebunan ternyata memiliki potensi yang besar sebagai pakan karena kandungan proteinnya yang cukup tinggi (Mullik, 2002 dan Hai et al, 2012). Salah satu kelemahan SBP adalah adanya metabolit sekunder seperti tanin, alkaloid, phlobatanin, steroid, terpenoid dan flavonoid serta bau menyengat yang berasal dari senyawa fitokimia yang dikandungnya (Akinmoladun et al., 2010 dan Ikhimioya et al., 2007). Sehingga dalam pemanfaatannya diperlukan berbagai pengolahan baik secara fisik, kimia dan biologi. Salah satu cara untuk menurunkan senyawa metabolit sekunder adalah dengan pembuatan silase (Bira et al., 2017). Mulik et al. (2016) melaporkan bahwa metode pengolahan silase tanpa aditif mampu menurunkan $62 \%$ kandungan total tanin Chromolaena odorata.

Silase adalah pengawetan hijauan segar dengan metode fermentasi dan dalam kondisi anaerob dengan tujuan untuk menambah daya simpan hijauan sehingga dapat dimanfaatkan dalam waktu yang lama terutama pada saat musim kemarau (Wati et al., 2018). Silase dipengaruhi oleh adanya bakteri asam laktat dimana bakteri asam laktat berfungsi untuk mengoptimumkan fase ensilase, dianjurkan untuk ditambahkan aditif seperti inokulum bakteri asam laktat dan aditif lainnya untuk menjamin berlangsungnya fermentasi asam laktat yang sempuma (Ridwan et al., 2005). Inokulum bakteri asam laktat merupakan aditif yang populer diantara aditif lainnya yakni bahan sumber karbohidrat (Bolsen et al., 1995). Aditif dari jenis sumber karbohidrat cukup beragam mulai dari dedak padi, tepung jagung, pollard sampai pada jenis umbi-umbian dan masingmasing aditif mempunyai kekurangan dan kelebihannya. Pada penelitian ini digunakan jenis aditif sumber karbohidrat yang berasal dari jenis dedak padi, tepung gaplek dan tepung jagung yang ketersediaannya cukup melimpah di alam serta memiliki nilai nutrisi yang diduga akan meningkatkan kualitas silase SBP, yang dapat dilihat berdasarkan karakteristik fisik maupun kimianya.

\section{MATERI DAN METODE}

\section{Alat dan Bahan}

Alat yang digunakan adalah toples plastik berkapasitas 3 liter sebagai silo, alat potong, timbangan analitik, $\mathrm{pH}$ meter, alat tulis menulis serta peralatan uji proksimat. Sedangkan bahannya adalah daun semak bunga putih, lamtoro, dedak padi, tepung gaplek dan tepung jagung dan bahan uji proksimat.

\section{Metode Penelitian}

Metode penelitian yang digunakan dalam penelitian ini adalah Rancangan Acak Lengkap (RAL) yang terdiri dari 4 perlakuan dan 4 ulangan yang terdiri dari :

R0 : Semak bunga putih $(70 \%)+$ Lamtoro (30\%) (kontrol)

R1 : Semak bunga putih (70\%) + Lamtoro (20\%) + Dedak Padi $(10 \%)$

R2 : Semak bunga putih (70\%) + Lamtoro (20\%) + Tepung Gaplek (10\%)

R3 : Semak bunga putih $(70 \%)+$ Lamtoro $(20 \%)$ + Tepung Jagung (10\%)

Persentase dedak padi, tepung jagung dan tepung gaplek dihitung berdasarkan berat cacahan daun SBP dan lamtoro dalam kondisi layu.

\section{Pembuatan Silase dan Prosedur Pengambilan Data}

Daun SBP dan lamtoro diambil pada masa sebelum berbunga dan dilayukan selama 3 jam untuk menurunkan kadar air (60-70\%). Daun SBP dan lamtoro dipotong dengan ukuran $\pm 3 \mathrm{~cm}$ dan dicampur dengan aditif (dedak padi atau tepung gaplek atau tepung jagung) masingmasing sebanyak $10 \%$ dari berat cacahan daun SBP. Adonan SBP yang telah dicampurkan dengan aditif dimasukkan ke dalam silo sedikit demi sedikit sambil ditekan untuk mengeluarkan oksigen, kemudian dibiarkan untuk proses ensilage selama 21 hari pada suhu kamar.

Setelah 21 hari toples dibuka dan diamati karakteristik fisik berupa aroma, tekstur, warna, dan keberadaan jamur dengan pengujian sensori. Sampel kemudian diambil dan dikeringkan dalam oven $60^{\circ} \mathrm{C}$ selama 2 hari dan dilanjutkan dengan analisis proksimat. 
Tabel 1. Kandungan nutrisi bahan pakan dalam pembuatan silase SBP

\begin{tabular}{|c|c|c|c|c|c|}
\hline \multirow[b]{2}{*}{ Kandungan Nutrisi } & \multicolumn{5}{|c|}{ Bahan Pakan } \\
\hline & $\begin{array}{l}\text { Semak Bunga } \\
\text { Putih }\end{array}$ & $\begin{array}{c}\text { Leucaena } \\
\text { leucocephala }\end{array}$ & Dedak & Jagung & Gaplek \\
\hline BK (\%) & 85,985 & 90,50 & 85,753 & 84,463 & 89,680 \\
\hline $\mathrm{BO}(\% \mathrm{BK})$ & 84,672 & 84,13 & 84,220 & 82,149 & 75,982 \\
\hline PK $(\% \mathrm{BK})$ & 19,034 & 24,95 & 7,012 & 1,231 & 4,484 \\
\hline LK $(\% \mathrm{BK})$ & 4,542 & 5,16 & 6,939 & 5,667 & 0,542 \\
\hline SK $(\% \mathrm{BK})$ & 8,490 & 18,29 & 26,953 & 0,561 & 1,805 \\
\hline $\mathrm{CHO}^{* *}(\% \mathrm{BK})$ & 61,095 & 54,12 & 64,559 & 80,375 & 71,541 \\
\hline BETN**(\%BK) & 52,605 & 34,12 & 37,606 & 79,814 & 69,737 \\
\hline \multicolumn{6}{|l|}{ Gross Energy** } \\
\hline $\mathrm{MJ} / \mathrm{Kg} \mathrm{BK}$ & 16,732 & 17,24 & 16,009 & 14,388 & 14,623 \\
\hline \multirow{2}{*}{$\begin{array}{c}\mathrm{Kkal} / \mathrm{Kg} \mathrm{BK} \\
\mathrm{EM}(\mathrm{Kkal} / \mathrm{Kg} \mathrm{BK})\end{array}$} & 3983,90 & 4088,75 & 3811,77 & 3425,81 & 3481,60 \\
\hline & & & & \multirow{2}{*}{3482,39} & 89,680 \\
\hline $\begin{array}{c}\mathrm{EM}(\mathrm{Kkal} / \mathrm{Kg} \mathrm{BK}) \\
\mathrm{Kkal} / \mathrm{Kg} \mathrm{BK}\end{array}$ & 3363,55 & & 2388,59 & & 75,982 \\
\hline \multicolumn{6}{|c|}{$\begin{array}{l}\text { Keterangan : BK : Bahan Kering, PK : Protein Kasar, LK : Lemak Kasar, SK : Serat Kasar, CHO : Karbohidrat, } \\
\text { BETN : Bahan Ekstrak Tanpa Nitrogen, EM : energy metabolis, ** : Perhitungan dari parameter. Hasil analisis } \\
\text { laboratorium Kimia Pakan Fakultas Peternakan Universitas Nusa Cendana, Kupang }(2020) .\end{array}$} \\
\hline \multicolumn{6}{|c|}{ Tabel 2. Skor penilaian kualitas fisik silase SBP } \\
\hline \multirow{2}{*}{$\begin{array}{l}\text { Parameter } \\
\text { kualitas fisik } \\
\text { silase SBP }\end{array}$} & \multicolumn{5}{|c|}{ Skoring } \\
\hline & \multicolumn{2}{|l|}{3} & 2 & & 1 \\
\hline Warna & $\begin{array}{l}\text { Hijau alami atau } \\
\text { kekuningan }\end{array}$ & $\begin{array}{l}\mathrm{Hij} \\
\mathrm{kec}\end{array}$ & $\begin{array}{l}\text { gelap atau } \\
\text { atan }\end{array}$ & Cokl & ıpai hitam \\
\hline Tekstur & Padat & & embek & Lem & \\
\hline Aroma & Asam (tetap sega & $\begin{array}{l}\text { Tic } \\
\text { bus }\end{array}$ & asam atau & Busu & \\
\hline
\end{tabular}

\section{Variabel Penelitian}

Kualitas Fisik Silase : aroma, tekstur, warna serta keberadaan jamur dilakukan dengan pengujian secara sensori yakni dengan pemberian skoring. Persentase jamur diukur dengan menimbang jumlah bagian berjamur dan dibandingkan dengan jumlah total silase, sedangkan $\mathrm{pH}$ diukur menggunakan $\mathrm{pH}$ meter.

Kualitas kimia silase : Kandungan Bahan Kering (BK), Kandungan Protein Kasar (PK), Lemak kasar (LK), Serat Kasar (SK) silase SBP melalui analisis proksimat (AOAC, 1990).

\section{Analisis Data}

Data dianalisis menggunakan sidik ragam (ANOVA) dan dilanjutkan dengan uji jarak berganda duncan untuk melihat perbedaan antar perlakuan. Analisis data menggunakan perangkat lunak SPSS versi 19.

\section{HASIL DAN PEMBAHASAN}

\section{Karakteristik Fisik Silase Semak Bunga Putih}

\section{Warna}

Warna silase pada Tabel 2 berkisar antara 2,13-2,62 atau berada pada warna kuning kecoklatan sampai mendekati warna hijaua alami atau hijau kekuningan. Warna silase menunjukkan normalnya proses fermentasi (ensilage). Hasil penelitian menunjukkan bahwa perlakuan berpengaruh nyata $(\mathrm{P}<0,05)$ lebih tinggi dari perlakuan kontrol. Hal ini dapat disebabkan karena pengaruh dari penambahan karbohidrat mudah larut. Karbohidrat mudah larut yang ditambahkan berupa dedak padi, gaplek dan jagung akan memberikan respon terhadap kinerja dari produksi bakteri asam laktat sehingga proses fermentasi berjalan dengan efektif. Walaupun tidak ada perbedaan antara R1, R2 dan R3 namun secara numerik, R2 lebih tinggi dan diikuti R3 kemudian R1. Hal ini berkaitan dengan kandungan $\mathrm{CHO}$ pada masingmasing bahan. Dimana, gaplek CHOnya lebih 
Tabel 3. Pengaruh penambahan jenis karbohidrat terlarut terhadap kualitas fisik silase semak bunga putih (Chromolaena odorata)

\begin{tabular}{ccccc}
\hline \multirow{2}{*}{ Variabel } & \multicolumn{4}{c}{ Perlakuan } \\
\cline { 2 - 5 } & R0 (Kontrol) & R1 & R2 & R3 \\
\hline Warna & $2,13 \pm 0,22^{\mathrm{b}}$ & $2,45 \pm 0,17^{\mathrm{a}}$ & $2,62 \pm 0,06^{\mathrm{a}}$ & $2,53 \pm 0,17^{\mathrm{a}}$ \\
Aroma & $2,20 \pm 0,33^{\mathrm{b}}$ & $2,58 \pm 0,22^{\mathrm{a}}$ & $2,60 \pm 0,08^{\mathrm{a}}$ & $2,55 \pm 0,17^{\mathrm{a}}$ \\
Tekstur & $2,35 \pm 0,12^{\mathrm{b}}$ & $2,53 \pm 0,09^{\mathrm{a}}$ & $2,63 \pm 0,05^{\mathrm{a}}$ & $2,58 \pm 0,09^{\mathrm{a}}$ \\
pH & $5,2 \pm 0,16^{\mathrm{a}}$ & $4,3 \pm 0,55^{\mathrm{b}}$ & $4,0 \pm 0,17^{\mathrm{b}}$ & $4,1 \pm 0,40^{\mathrm{b}}$ \\
Jamur & $6,25 \pm 1,73^{\mathrm{a}}$ & $2,37 \pm 1,80^{\mathrm{b}}$ & $1,56 \pm 1,82^{\mathrm{b}}$ & $1,96 \pm 1,42^{\mathrm{b}}$ \\
\hline
\end{tabular}

Keterangan : Data disajikan dalam \pm SD; R0: Semak bunga putih (70\%) + Lamtoro (30\%) (kontrol); R1: Semak bunga putih $(70 \%)+$ Lamtoro $(20 \%)+$ Dedak Padi $(10 \%)$; R2: Semak bunga putih $(70 \%)+$ Lamtoro $(20 \%)+$ Tepung Gaplek (10\%); R3: Semak bunga putih (70\%) + Lamtoro (20\%) + Tepung Jagung (10\%).

Nilai dengan superskrip yang berbeda dalam baris yang sama menunjukkan pengaruh yang berbeda nyata $(\mathrm{P}<0.05$ ). Warna (3.Hijau alami atau hijau kekuningan; 2.Hijau gelap atau kuning kecoklatan; 1.Coklat sampai hitam), Aroma (3. Asam/tetap segar; 2. Tidak asam atau tidak busuk; 1. Busuk), Tekstur (3. Padat; 2. Agak lembek; 1. Lembek).

tinggi daripada jagung dan dedak padi (Tabel 1). Penambahan sumber karbohidrat diharapkan dapat mudah larut dan dapat dengan cepat dimanfaatkan oleh BAL sebagai nutisi untuk pertumbuhannya (Ridwan et al., 2005) sehingga warna yang dihasilkan sama ataupun mendekati warna alami bahannya. Hadirnya sumber karbohidrat terlarut dapat mengoptimalkan pertumbuhan dan fungsi bakteri untuk memfermentasi SBP sehingga dapat dimanfaatkan oleh ternak. Hal ini juga dapat menurunkan antinutrisi yang dikandung SBP. Sesuai pendapat Waktu fermentasi 21 hari merupakan perlakuan yang tertinggi dalam menurunkan kandungan total tanin silase SBP bila dibanding dengan waktu fermentasi 0 hari (Ridla et al., 2016).

\section{Aroma}

Skoring aroma silase berbahan dasar SBP silase yang dihasilkan berkisar 2,20-2,60 atau beraroma tidak asam sampai beraroma asam atau tetap segar. Hasil penelitian menunjukkan pengaruh nyata $(\mathrm{P}<0,05)$ antara kontrol dengan yang ditambahkan sumber karbohidrat mudah larut. Hal ini mengindikasikan bahwa bakteri asam laktat tumbuh dan berkembang dengan yang yang ditandai dengan aroma asam. Aroma khas silase adalah beraroma asam (Utomo et al., 2013). Hal ini sesuai pendapat (Nahak et al., 2019) bahwa penggunaan aditif akan berpengaruh terhadap aroma silase komplit berbahan dasar hijauan sorgum. Aroma yang dihasilkan juga sangat berkaitan dengan $\mathrm{pH}$. $\mathrm{pH}$ yang asam memberikan aroma yang asam pula karena ciri khas dari bakteri asam laktat yakni beraroma asam.

\section{Tekstur}

Hal yang sama terhadap tekstur silase chromolaena odorata yakni menunjukkan tekstur agak lembek sampai padat atau memiliki skor 2,35-2,63. Dimana ada pengaruh penambahan sumber karbohidrat terlarut terhadap tekstur yang dihasilkan dan ada perbedaan antara kontrol dengan perlakuan. Tekstur silase mengindikasikan bahwa selain karena karbohidrat mudah larut yang ditambahkan juga karena proses pengisian silo yang tepat sehingga dapat menciptakan suasana anaerob. Hal yang sama disampaikan oleh (Muhammad et al., 2017) bahwa proses pengisian silo baik dan cepat serta kondisi anaerobik menghasilkan suasana asam yang tepat sehingga bakteri asam laktat dapat bekerja dengan maksimal. Demikian pula (Kurnianingtyas et al., 2012), bahwa prinsip dari pembuatan silase ini adalah untuk menghentikan kontak antara hijauan dengan oksigen, sehingga dengan keadaan anaerob ini bakteri asam laktat akan tumbuh dengan mengubah karbohidrat mudah larut menjadi asam laktat.

\section{pH}

Ada beberapa faktor yang cukup menentukan kualitas fermentasi yang dihasilkan dalam pembuatan silase, diantaranya adalah jenis hijauan yang digunakan, kadar air pada bahan dan aditif (Tahuk et al., 2020). Dalam penelitian ini pakan konvensional yang dimanfaatkan adalah SBP dengan penambahan karbohidrat terlarut dan dihasilkan ada perbedaan yang cukup signifikan antara kontrol dan perlakuan. Hal ini dapat ditunjukkan dengan $\mathrm{pH}$ yang dihasilkan dikategorikan sebagai $\mathrm{pH}$ yang baik sekali sampai $\mathrm{pH}$ baik dengan kisaran 4,0-4,3 untuk 
perlakuan sedangkan dan 5,2 untuk kontrol dan dikategorikan sebagai $\mathrm{pH}$ yang sedang. Hasil ini sama dengan (Rahayu et al., 2017), bahwa silase dengan $\mathrm{pH}$ antara 4,2-4,5 merupakan silase yang berkualitas baik. $\mathrm{pH}$ yang dihasilkan dalam penelitian ini seiring dengan warna, aroma dan tekstur yang dihasilkan. Semakin rendah $\mathrm{pH}$ (asam) akan menghasilkan kualitas organoleptik yang khas yakni warna hijau alami, beraroma asam dan bertekstur padat. walaupun tidak ada perbedaan antara R1, R2 dan R3 namun R2 menghasilkan nilai $\mathrm{pH}$ yang baik sekali. Hal ini sebagai akibat dari banyaknya karbohidrat yang terkandung dalam gaplek (Tabel 1).

\section{Jamur}

Jamur yang diperoleh dari penelitian ini diukur dengan menimbang jumlah bagian berjamur dan dibandingkan dengan jumlah total silase. Hasilnya menunjukkan bahwa jamur yang tumbuh paling sedikit adalah pada perlakuan penambahan sumber karbohidrat terlarut (R1, R2 dan R3) sedangkan kontrol (R0) terbanyak ditumbuhi jamur. Hal ini mengindkasikan bahwa bakteri yang tumbuh dan berkembang adalah bakteri asam laktat dibanding bakteri patigen lainnya yang menyebabkan tumbuhnya jamur. Hal ini diperkuat oleh Hidayat (2014) bahwa, percepatan laju pembentukan asam laktat tergantung dengan jumlah ketersediaan karbohidrat mudah larut dan enzim komplek yang tersedia. Keadaan asam akan menghambat pertumbuhan bakteri patogen lain selain bakteri asam laktat.

\section{Bahan Kering dan Bahan Organik}

Tabel 4 menunjukkan bahwa ada pengaruh penambahan sumber karbohidrat terlarut terhadap BK silase SBP. Hal ini menunjukkan bahwa penambahan karbohidrat terlarut dapat menyediakan substrat untuk memenuhi aktifitas bakteri asam laktat dalam proses fermentasi. Tujuan dari penambahan karbohidrat terlarut diantaranya untuk meningkatkan kinerja bakteri asam laktat dan menciptakan kondisi asam sehingga dapat menghalangi pertumbuhan bakteri pembusuk. Penambahan karbohidrat terlarut akan meningkatkan kemampuan bakteri asam laktat dan berakibat pada penurunan kandungan BK (Ridwan et al., 2005 dan McDonald, 1991 dan). Namun dalam penelitian ini tidak terjadi penurunan kandungan BK karena adanya penambahan Leucaena leucocephala dengan kandungan BK yang tinggi sehingga dapat menyeimbangkan kadar BK yang hilang akibat proses fermentasi.

Penambahan karbohidrat terlarut yang berbeda memberikan pengaruh yang berbeda nyata terhadap kandungan BO silase semak bunga putih. Data Tabel 4 memperlihatkan bahwa kandungan BO kontrol (R0) berbeda dengan perlakuan (R1, R2 dan R3). Adanya perbedaan ini sebagai akibat dari penambahan karbohidrat terlarut sampai $10 \%$. Kandungan BO yang dihasilkan dalam penelitian ini berkisar antara 82,95-88,14\%. Dimana, kandungan BO ini sedikit lebih tinggi dari laporan Jasin (2014) pada silase rumput gajah yang ditambahkan molases dan cairan rumen sapi yang hanya mendapat kandungan BO sebesar 76,96-79,75\%. Hal ini karena jumlah persentase penambahan yang lebih tinggi dari penelitian ini. Penambahan karbohidrat mudah terlarut terbukti dapat menigkatkan kandungan bahan organik silase SBP dibandingkan kontrol. Hal ini didukung oleh Santoso et al. (2009) bahwa tingginya kandungan bahan organik silase diakibatkan oleh adanya tambahan karbohidrat mudah larut yang dapat dimanfaatkan oleh bakteri.

\section{Protein Kasar, Lemak Kasar dan Serat Kasar}

Terjadi penurunan kandungan PK dalam pembuatan silase SBP yang diakibatkan oleh adanya aktifitas bakteri asam laktat. Bakteri memanfaatkan protein yang berasal dari SBP dan bahan karbohidrat mudah larut untuk melaksanakan aktifitasnya seperti meningkatkan populasi. Kandungan PK tertinggi terdapat pada perlakuan R1 dan terendah pada perlakuan R2 dan R3. Hal ini berkaitan dengan respon bakteri asam laktat yang lebih aktif dan cepat mendegradasi tepung gaplek dan tepung jagung sehingga kehilangan protein kasar semakin cepat. Walaupun kandungan PK SBP dan leucaena leucocephala tergolong tinggi namun bakteri asam laktat lebih mudah mendegradasi PK untuk aktifitas hidupnya. Tingginya kandungan PK pada R0 sebagai akibat kurangnya pasokan energi yang berasal dari karbohidrat mudah larut sehingga bakteri tidak begitu aktif dalam mendegradasi PK. Kuncoro et al. (2015) menjelaskan bahwa peningkatan dan penurunan kadar protein yang terjadi dapat disebabkan karena kemampuan bakteri asam laktat dalam mendegradasi protein. Kandungan PK silase SBP yang dihasilkan dalam penelitian ini juga berkaitan erat dengan kandungan PK bahan yang 
Tabel 4. Pengaruh penambahan jenis karbohidrat terlarut terhadap kualitas kimia silase semak bunga putih (Chromolaena odorata)

\begin{tabular}{lcccc}
\hline \multirow{2}{*}{ Variabel } & \multicolumn{4}{c}{ Perlakuan } \\
\cline { 2 - 5 } & R0 (Kontrol) & R1 & R2 & R3 \\
\hline Bahan Kering (\%BK) & $92,95 \pm 0,94^{\mathrm{c}}$ & $96,38 \pm 1,51^{\mathrm{ab}}$ & $94,08 \pm 2,69^{\mathrm{cb}}$ & $97,45 \pm 1,69^{\mathrm{a}}$ \\
Bahan Organik (\%BK) & $82,95 \pm 1,81^{\mathrm{c}}$ & $85,12 \pm 1,22^{\mathrm{bc}}$ & $87,08 \pm 2,14^{\mathrm{ab}}$ & $88,14 \pm 1,48^{\mathrm{a}}$ \\
Protein Kasar (\%BK) & $16,79 \pm 0,29^{\mathrm{b}}$ & $17,42 \pm 0,26^{\mathrm{a}}$ & $15,71 \pm 0,13^{\mathrm{c}}$ & $15,50 \pm 0,26^{\mathrm{c}}$ \\
Lemak Kasar (\%BK) & $5,78 \pm 0,68^{\mathrm{b}}$ & $7,59 \pm 0,73^{\mathrm{a}}$ & $4,45 \pm 0,51^{\mathrm{c}}$ & $6,09 \pm 0,36^{\mathrm{b}}$ \\
Serat Kasar (\%BK) & $13,07 \pm 0,91^{\mathrm{a}}$ & $10,68 \pm 0,60^{\mathrm{b}}$ & $10,33 \pm 0,44^{\mathrm{b}}$ & $7,82 \pm 0,54^{\mathrm{c}}$ \\
\hline
\end{tabular}

Keterangan : Data disajikan dalam \pm SD; R0: Semak bunga putih (70\%) + Lamtoro (30\%) (kontrol); R1: Semak bunga putih $(70 \%)+$ Lamtoro $(20 \%)+$ Dedak Padi (10\%); R2: Semak bunga putih $(70 \%)+$ Lamtoro $(20 \%)+$ Tepung Gaplek (10\%); R3: Semak bunga putih (70\%) + Lamtoro (20\%) + Tepung Jagung (10\%).

Nilai dengan superskrip yang berbeda dalam baris yang sama menunjukkan pengaruh yang berbeda nyata $(\mathrm{P}<0.05)$. BK : Bahan Kering; BETN : Bahan Ekstrak Tanpa Nitrogen; CHO : Karbohidrat.

digunakan. Dimana, PK dedak padi (7,01\%) lebih tinggi dari tepung jagung $(4,48 \%)$ dan tepung gaplek $(1,23 \%)$.

Hasil penelitian menunjukkan bahwa penambahan sumber karbohidrat terlaru berpengaruh nyata terhadap kandungan LK. Hasil uji lanjut menunjukkan bahwa R0 dan R3 tidak berbeda namun berbeda dengan R1 dan R2. Kandungan LK yang dihasilkan umumnya hampir sama dengan kandungan nutrisi lainnya yakni sangat berkaitan erat dengan kandungan LK bahan yang digunakan. Kandungan LK pada dedak lebih tinggi dari tepung jagung dan tepung gaplek (Tabel 3). Pada dasarnya ketika proses fermentasi berjalan maka aktivitas bakteri akan semakin tinggi dalam menghasilkan asam lemak. Juwandi et al. (2018) menyatakan bahwa Hasil penguraian karbohidrat dalam proses fermentasi dapat menghasilkan asam-asam lemak. Penggunaan Leucaena leucocephala juga turut menyumbangkan asam lemak akibatnya kandungan lemak kasar akan meningkat.

Penambahan karbohidrat terlarut berpengaruh nyata terhadap kandungan SK silase. dimana, perlakuan menghasilkan SK yang rendah dibandingkan kontrol. SK silase SBP yang dihasilkan sejalan dengan SK bahan karbohidrat terlarut yang digunakan. Demikian pula dengan kemampuan bakteri asam laktat dalam mendegradasi serat kasar. Tingginya SK pada kontrol sebagai akibat dari kurangnya energi bagi kebutuhan bakteri asam laktat hal ini juga ditandai dengan $\mathrm{pH}$ yang tinggi (Tabel 3 ). Kemampuan bakteri terkait dengan penambahan sumber karbohidrat terlarut sebagai makanannya. Selama proses ensilase, bakteri dapat mendegradasi dan merombak lignoselulosa dan hemilignoselulosa pada proses fermentasi (Laksono dan Karyono, 2020; Sobowole et al.,
2007) dan hal ini akan berakibat pada rendahnya SK yang dihasilkan.

\section{KESIMPULAN}

Disimpulkan bahwa penambahan tepung gaplek berpengaruh dan nyata lebih tinggi dalam menghasilkan karakteristik fisik silase semak bunga putih yang terbaik. Pada karakteristik kimia, penambahan dedak padi sebagai karbohidrat terlarut nyata lebih tinggi dibandingkan dengan tepung gaplek dan tepung jagung.

\section{DAFTAR PUSTAKA}

Akinmoladun, A. C., E. M. Obuotor and E. O. Farombi. 2010. Evaluation of antioxidant and free radical scavenging capacities of some Nigerian indigenous medicinal plants. J. Med. Food 13: 444- 451. DOI: https://doi.org/10.1089/jmf.2008.0292

Bira, G.F., M.L. Mullik., Dahlanuddin. 2017. Incremental Level of Chromolaena odorata In Complete Diet For a Cows Fattening. The $7^{\text {th }}$ International Seminar on Tropical Animal Production (ISTAP) : p 68-72. ISBN : 978-979-1215-29-9.

Bolsen, K.K., Ashbell, M.G and J.M. Wilkinnson.1995. Silage Additivesin Biotechnology in Animal Feeding. In: R. J. Wallace and A. Chesson (eds). VCH. Weinheim

Hai, P. V., H. Everts, D. V. Tien, J. T. Schonewille and W. H. Hendriks. 2012. Feeding Chromonaela odorata during 
pregnancy to goat dams affects acceptance of this feedstuff by their offspring. Appl. Anim. Behav. Sci. 137: 30-35.

DOI: https://doi.org/10.1016/j.applanim.2012.0 $\underline{1.010}$

Hidayat, N. 2014. Karakteristik dan Kualitas Silase Rumput Raja Menggunakan Berbagai Sumber dan Tingkat Penambahan Karbohidrat Fermentable. Agripet. 14 (1) : 42-49. DOI: https://doi.org/10.17969/agripet.v14i1.12 $\underline{04}$

Ikhimoya, I., M. A. Bamikole, A.U. Omoregie. and U. J. Ikhatua. 2007. Compositional Evaluation of Some Dry Season Shrub and Tree Foliages in a Transitionally Vegetated Zone of Nigeria. Livestock Research for Rural Development 19 (3) : $1-9$.

Jasin, I. 2014. Pengaruh Penambahan Molases dan Isolat Bakteri Asam Laktat dari Cairan Rumen Sapi PO Terhadap Kualitas Silase Rumput Gajah (Pennisetum purpureum). Agripet, 14 (1) : 50-55. DOI: https://doi.org/10.17969/agripet.v14i1.12 $\underline{05}$

Juwandi., Munir dan Fitriana. 2018. Evaluasi Kandungan Lemak Kasar dan BETN Silase Daun Lamtoro pada Level yang Berbeda Sebagai Bahan Pakan Utama Pakan Komplit. Bionature 19 (2) : 112118.

DOI: https://doi.org/10.35580/bionature.v19i2. $\underline{9728}$

Kuncoro, D. C., Muhtaruddin dan F. Fathul. 2015. Pengaruh Penambahan Berbagai Starter Pada Silase Ransum Berbasis Limbah Pertanian Terhadap Protein Kasar, Bahan Kering, Bahan Organik, dan Kadar Abu. Jurnal Ilmiah Peternakan Terpadu 3 (4) : 234-238. DOI:http://dx.doi.org/10.23960/jipt.v3i4. $\mathrm{p} \% 25 \mathrm{p}$

Kurnianingtyas, I.B., P.R. Pandansari., I. Astuti., S.D. Widyawati dan W.P.S. Suprayogi. 2012. Pengaruh Macam Akselerator Ttrhadap Kualitas Fisik, Kimia dan
Biologis Silase Rumput Kolonjono. Tropical Animal Husbandry 1 (1) : 7-14.

Laksono, J dan T. Karyono. 2020. Pemberian level starter pada silase jerami jagung dan legum Indigofera zollingeriana terhadap nilai nutrisi pakan ternak ruminansia kecil. Jurnal Peternakan 04 (1):33-38.

DOI: http://dx.doi.org/10.31604/jac.v4i1.1420

McDonald, P., A. R. Henderson, S. J. E. Heron. 1991. The Biochemistry of Silage. Chalcombe Publications. Aberyswyth.

Muhammad, N., A. Astuti, R. Utomo dan S. P. S. Budi. 2017. Physical Characteristics Evaluation of Kumpai Minyak Grass (Hymenachne amplexicaulis) Silage. Procedding The $7^{\text {th }}$ International Seminar on Tropical Animal Production, September 12-14. Yogyakarta, Indonesia. p : 200-204. ISBN : 978-979-1215-29-9.

Mulik, Y. M., M. Ridla, I. Prihantoro and M. L. Mullik. 2016. Anaerobic fermentation effectively reduces concentration of total tannins in Siam Weed (Chromolaena odorata). Jurnal Ilmu Ternak dan Veteriner 21: 19-21. DOI: https://doi.org/10.21059/buletinpetern ak.v40i3.12838

Mullik, M.L. 2002. Laporan penelitian: Strategi Pemanfaatan Semak Bunga Putih (Chromolaena odorata) untuk Meningkatkan Produksi Ternak dan Pendapatan Peternak di Daerah Lahan Kering. Kerjasama Fakultas Peternakan Universitas Nusa Cendana dan Kementrian Riset dan Teknologi Republik Indonesia melalui Riset Pengembangan Kapasitas.

Nahak, O.R., P. K. Tahuk., G. F. Bira., A. Bere dan H. Riberu. 2019. Pengaruh Penggunaan Jenis Aditif yang Berbeda terhadap Kualitas Fisik dan Kimia Silase Komplit Berbahan Dasar Sorgum (Shorgum bicolor (L.) Moench). Journal of Animal Science 4 (1) : 3-5. DOI: https://doi.org/10.32938/ja.v4i1.649 
Rahayu, I. D., L. Zalizar., A. Widianto dan M. I. Yulianto. 2017. Karakteristik dan Kualitas Silase Tebon Jagung (Zea mays) Menggunakan Berbagai Tingkat Penambahan Fermentor yang Mengandung Bakteri Lignochloritik. Prosiding. Seminar nasional dan Gelar produk (Senaspro), Universitas Muhammadiyah Malang, Hal : 730-737.

Ridla, M., Y. M. Mulik., I. Prihantoro dan M. M. Mullik. 2016. Penurunan Total Tanin Silase Semak Bunga Putih (Chromolaena odorata) dengan Aditif Tepung Putak (Coryphaelata Roxb) dan Isi Rumen Sapi. Buletin Peternakan 40 (3): 165-169. DOI: https://doi.org/10.21059/buletinpetern ak.v40i3.12838.

Ridwan, R., S. Ratnakomala., G. Kartina dan Y. Widyastuti. 2005. Pengaruh Penambahan Dedak Padi dan Lactobacillus plantarum 1BL-2 dalam Pembuatan Silase Rumput Gajah (Pennisetum Purpureum). Media Peternakan 28 (3) : 117-123.

Santoso, B., B. Tj. Hariadi, H. Manik dan H. Abubakar. 2009. Kualitas rumput unggul tropika hasil ensilase dengan aditif bakteri asam laktat dari ekstrak rumput terfermentasi. Media Peternakan 32: 137144. 